\title{
Effect of Aegle marmelos methanolic extracts of leaf and fruit pulp on learning and memory in albino rats
}

\author{
Pojala Kumar ${ }^{1}$, Krishnakanth K. ${ }^{2 *}$, Jagadeesh Alla ${ }^{2}$
}

\begin{abstract}
${ }^{1}$ Department of Pharmacology, Dr Pinnamaneni Siddhartha Institute of Medical Sciences, Chinaoutpalli, Krishna, Andhra Pradesh, India

${ }^{2}$ Department of Pharmacology, NRI Medical College and Hospital, Chinakakani, Guntur, Andhra Pradesh, India
\end{abstract}

Received: 02 February 2020

Revised: 17 February 2020

Accepted: 18 February 2020

*Correspondence:

Dr. Krishnakanth K.,

Email: kkrishnakanth27@gmail.com

Copyright: (c) the author(s), publisher and licensee Medip Academy. This is an open-access article distributed under the terms of the Creative Commons Attribution Non-Commercial License, which permits unrestricted non-commercial use, distribution, and reproduction in any medium, provided the original work is properly cited.

\begin{abstract}
Background: The objective was to study the effect of Aegle marmelos methanolic extracts of leaf (LE) and fruit pulp extract (FE) on learning and memory in albino rats. 40 healthy wistar albino rats of either sex were randomly divided into 10 groups of 4 each $(n=4)$, weighing about 150 to $200 \mathrm{gm}$ were selected for the study. The extracts i.e. $1 \mathrm{ml}$ of $1 \%$ carboxy methyl cellulose, LE and FE at doses of $100 \mathrm{mg} / \mathrm{kg}$ and $200 \mathrm{mg} / \mathrm{kg}$ were administered per oral one hour before the experiment.

Methods: Learning and memory was assessed by elevated plus maze and Hebb William maze. Latency time and number of entries were assessed by elevated plus maze whereas only latency was assessed by Hebb William maze.

Results: Plant extracts of LE and FE at doses $100 \mathrm{mg} / \mathrm{kg}$ and $200 \mathrm{mg} / \mathrm{kg}$ have shown significant percentage reduction in latency time in elevated plus maze and Hebb William maze $(\mathrm{p}<0.05)$ and reduction in the number of entries in elevated plus maze.

Conclusions: LE and FE at doses $200 \mathrm{mg} / \mathrm{kg}$ have shown significant effect on learning and memory.
\end{abstract}

Keywords: Learning, Memory, Elevated plus maze, Hebb William maze, Aegle marmelos

\section{INTRODUCTION}

Cognition is the process of acquiring knowledge and understanding through thought, experience, and reasoning. Cognitive functions are memory, attention, creativity and intelligence. It is affected by factors like stress, ageing, hypertension. Cognitive enhancement is extension of core capacities of the mind through improvement or augmentation of internal or external information processing systems. ${ }^{1}$ Cognition enhancement strategies are nutrients, herbal medicines, exercise and drugs. Memory is of short term lasting from seconds to minutes, intermediate long term memory lasting from days to weeks and long term memory lasting for years.
Nootropic drugs such as piracetam, aniracetam and donezipil are being used for improving memory, mood and behaviour but the resulting side effects associated with them have limited their use in patients. According to WHO, nearly $80 \%$ of the population in developing countries are dependent on traditional medical practices relying on plant-based drugs for their primary health care needs. ${ }^{2}$

Medicinal plants are sources of chemical substances with potential therapeutic effects and literature has documented plants with putative analgesic and antiinflammatory activities. ${ }^{3}$ To establish the use of herbal medicines in a scientific way with valid evidence, World 
Health Organisation and Indian Council of Medical Research are encouraging wide spread researches on herbal drugs. ${ }^{4}$

Aegle marmelos (Bael) is an Indian plant, which has enormous therapeutic value in traditional systems of medicine. It belongs to the family Rutaceae and grows in dry forest, shivaliks and found all over India and Asian countries. The different parts of bael tree are used for various therapeutic purposes, such as for treatment of fever, arthritis, fractures, healing of wounds, asthma, anaemia, jaundice, diarrhoea, typhoid, hypertension, diabetes mellitus and neurological disorders in traditional systems of medicine. ${ }^{5}$ There are few studies of Aegle marmelos having neuropsychopharmacological effects. With this back ground this study has been undertaken to evaluate the neuropsychopharmacological effects of the ethanolic extracts of leaf and fruit pulp of Aegle marmelos in albino rats.

\section{METHODS}

\section{Experimental animals}

Wistar albino rats (150 to $200 \mathrm{~g}$ ) of either sex were randomly divided into 10 groups of 4 rats in each group using computer generated randomization and Institutional Animal Ethical Committee clearance was obtained for carrying out the experiment. Rats were procured from Gentox Bioservices Pvt Ltd, Hyderabad. They were housed in animal room in air conditioned atmosphere at an ambient temperature of $25 \pm 1^{\circ} \mathrm{C}$, with alternative lightdark cycle of 12 hours each. They were fed with dry pellets and water adlibitum. Animals were kept fasting overnight and weighed before the experiment. All experiments were conducted between 0900 hours and 1700 hours.

\section{Preparation of extract ${ }^{6-7}$}

The leaves and unripe fruit of Aegle marmelos (Bael) were washed under tap water, dried under shade and pulverized to coarse powder. The dried powder was separately loaded into the Soxhlet apparatus and subjected to extraction for about 36 hours with $95 \%$ methanol. The extracts obtained separately were filtered, concentrated under reduced pressure on water bath below $500{ }^{\circ} \mathrm{C}$ and dried in rotary vacuum drier to get powder extract. The powder extract obtained was stored in an air tight container kept in refrigerator at $2-80{ }^{\circ} \mathrm{C}$ until further use.

\section{Test drugs}

Aegle marmelos: Drug (extract form) was dissolved in normal saline and administered orally with the help of feeding cannula in a doses of $100 \mathrm{mg} / \mathrm{kg}$ bw and $200 \mathrm{mg} /$ kg bw. ${ }^{8}$ It was purchased from market (Aegle marmelos extract, Himalaya Drug Company). Acute toxicity studies were done and doses were selected. It was similar to the study of Himani et al. ${ }^{8}$

\section{Animal experimental groups}

\section{For elevated plus maze method (total 5 groups)}

Group 1 was served as control, treated with $1 \mathrm{ml}$ of $1 \%$ carboxy methyl cellulose (CMC). Group 2 and 3 was treated with leaf extract (LE) by doses of 100 and 200 $\mathrm{mg} / \mathrm{kg}$. Group 4 and 5 was treated with fruit extract (LE) by doses of 100 and $200 \mathrm{mg} / \mathrm{kg}$

\section{For Hebb William maze method (total 5 groups)}

Group 1 was served as control, treated with $1 \mathrm{ml}$ of $1 \%$ CMC. Group 2 and 3 was treated with LE by doses of 100 and $200 \mathrm{mg} / \mathrm{kg}$. Group 4 and 5 was treated with LE by doses of 100 and $200 \mathrm{mg} / \mathrm{kg}$.

\section{Elevated plus-maze}

Elevated plus-maze served as the exteroceptive behavioural model to evaluate memory in rats. The elevated plus-maze apparatus for rats consisted of a central platform $(10 \times 10 \mathrm{~cm})$ connected to two open arms $(50 \times 10 \mathrm{~cm})$ and two covered (enclosed) arms $(50 \times 40 \times 10$ $\mathrm{cm}$ ), and the maze was elevated to a height of $50 \mathrm{~cm}$ from the floor. ${ }^{9}$ The procedure, technique, and end point for testing memory was followed as per the parameters described by the investigators working in the area of psychopharmacology. ${ }^{10}$ On the first day (i.e., seventh day of drug treatment), each rat was placed at the end of an open arm, facing away from the central platform. Transfer latency (TL) was defined as the time (in seconds) taken by the animal to move from the open arm into any one of the covered arms with all its four legs. TL was recorded on the first day (training session) for each animal. The rat was allowed to explore the maze for another $2 \mathrm{~min}$ and then returned to its home cage. Retention of this learned-task (memory) was examined 24 hour after the first day trial (i.e., eighth day, 24 hour after last dose). Significant reduction in TL value of retention indicated improvement in memory.

\section{Hebb William maze}

Hebb-Williams maze is an incentive-based exteroceptive behavioural model useful for measuring spatial working memory of rats. ${ }^{9}$ It mainly consists of three components: animal chamber (or start box), which is attached to the middle chamber (or exploratory area), and a reward chamber at the other end of the maze in which the reward (food) is kept. All three components are provided with guillotine removable doors. On the fourth day, the rat was placed in the animal chamber or start box and the door was opened to facilitate the entry of the animal into the next chamber. The door of the start box was closed immediately after the animal moved into the next chamber to prevent back-entry. Time taken by the animal 
to reach the reward chamber from the start box was recorded on the fourth day (training session) for each animal. Each animal was allowed to explore the maze for 3 min with all the doors opened before returning to its home cage. Retention of this learned task (memory) was examined on day 4 and day $8 .{ }^{10}$

\section{Statistical analysis}

All the results were expressed as mean \pm standard error (SEM). Data was analyzed using one-way ANOVA followed by paired $\mathrm{t}$ - test. $\mathrm{P}<0.05$ were considered as statistically significant.

\section{RESULTS}

\section{Effect on TL (using elevated plus-maze)}

TL of the second day reflected retention of information or memory. TL was significantly reduced in all the groups when compared with the control group $(1 \% \mathrm{CMC})$ from day 7 to day 8 . The percentage reduction in transfer latency from day 7 to day 8 in group 2 was $69.1 \%$ $(\mathrm{p}<0.05)$, group 3 was $79.7 \%(\mathrm{p}<0.05)$, group 4 was $72.3 \%(\mathrm{p}<0.05)$ and group 5 was $80.7 \%(\mathrm{p}<0.05)$ as seen in Table 1.

The percentage reduction in entries from day 7 to day 8 in group 1 was $11.1 \% \quad(\mathrm{p}<0.05)$, group 2 was $71.4 \%$ $(\mathrm{p}<0.05)$, group 3 was $80 \%(\mathrm{p}<0.05)$, group 4 was $70.6 \%$ $(\mathrm{p}<0.05)$ and group 5 was $82.4 \%(\mathrm{p}<0.05)$ as seen in Table 1.

\section{Effect on time taken to reach reward chamber (using Hebb-Williams maze)}

Time taken to reach the reward chamber (TRC) on the eighth day (24 hour after last dose) reflected the memory of animals. Significant reduction in TRC value indicated improvement in memory. Group 1 did not show any significant difference on TRC when compared on day 4 and day 8. There was significant difference in TRC in groups $2,3,4,5$ on TRC when compared between day 4 and day 8 as seen in Table 2 .

Table 1: Effect of leaf and fruit extract of Aegle marmelous on learning and memory using elevated plus maze.

\begin{tabular}{|c|c|c|c|c|c|c|c|c|}
\hline \multirow[b]{2}{*}{ Group } & \multicolumn{2}{|c|}{$\begin{array}{l}\text { TL }(\mathrm{sec}) \\
(\operatorname{mean} \pm \mathrm{SD})\end{array}$} & \multirow{2}{*}{$\begin{array}{l}\% \\
\text { reduction } \\
\text { in latency } \\
\text { from day } 7 \\
\text { to day } 8\end{array}$} & \multirow{2}{*}{$\begin{array}{l}\text { Paired } \\
t \text { test } \\
\text { (level of } \\
\text { signific } \\
\text { ance) }\end{array}$} & \multicolumn{2}{|c|}{$\begin{array}{l}\text { Number of entries } \\
(\text { mean } \pm \text { SD })\end{array}$} & \multirow{2}{*}{$\begin{array}{l}\% \\
\text { reduction } \\
\text { in latency } \\
\text { from day } \\
7 \text { to day } 8\end{array}$} & \multirow{2}{*}{$\begin{array}{l}\text { Paired } t \\
\text { test } \\
\text { (level of } \\
\text { significa } \\
\text { nce) }\end{array}$} \\
\hline & Day 7 & Day 8 & & & Day 7 & Day 8 & & \\
\hline Group 1 (1\% CMC) & $39.0 \pm 3.74$ & $35.3 \pm 5.12$ & 9.6 & $>0.05$ & $9 \pm 1.41$ & $8 \pm 2.00$ & 11.1 & $>0.05$ \\
\hline $\begin{array}{l}\text { Group } 2 \text { (leaf } 100 \\
\mathrm{mg} / \mathrm{kg} \text { bw) }\end{array}$ & $34.0 \pm 4.24$ & $10.5 \pm 4.93$ & 69.1 & $<.005$ & $8.75 \pm 0.96$ & $2.5 \pm 1.29$ & 71.4 & $<0.05$ \\
\hline $\begin{array}{l}\text { Group } 3 \text { (leaf } 200 \\
\mathrm{mg} / \mathrm{kg} \text { bw) }\end{array}$ & $33.3 \pm 2.75$ & $6.8 \pm 1.71$ & 79.7 & $<0.05$ & $8.75 \pm 0.96$ & $1.75 \pm 0.50$ & 80.0 & $<0.05$ \\
\hline $\begin{array}{l}\text { Group } 4 \text { (fruit } 100 \\
\mathrm{mg} / \mathrm{kg} \mathrm{bw} \text { ) }\end{array}$ & $37.0 \pm 4.40$ & $10.3 \pm 2.99$ & 72.3 & $<0.05$ & $8.5 \pm 0.58$ & $2.5 \pm 1.29$ & 70.6 & $<0.05$ \\
\hline $\begin{array}{l}\text { Group } 5 \text { (fruit } 200 \\
\mathrm{mg} / \mathrm{kg} \mathrm{bw} \text { ) }\end{array}$ & $36.3 \pm 2.99$ & $7.0 \pm 1.41$ & 80.7 & $<0.05$ & $8.5 \pm 1.29$ & $1.5 \pm 0.58$ & 82.4 & $<0.05$ \\
\hline
\end{tabular}

Table 2: Effect of leaf and fruit extract of Aegle marmelous on learning and memory using Hebb Williams maze.

\begin{tabular}{|c|c|c|c|c|}
\hline \multirow[t]{2}{*}{ Group } & \multicolumn{2}{|l|}{$\begin{array}{l}\text { TL }(\sec ) \\
(\text { Mean } \pm \text { SD })\end{array}$} & \multirow{2}{*}{$\begin{array}{l}\text { Percentage reduction in } \\
\text { latency from day } 4 \text { to } \\
\text { day } 8\end{array}$} & \multirow{2}{*}{$\begin{array}{l}\text { Paired } t \text { Test } \\
\text { (level of } \\
\text { significance) }\end{array}$} \\
\hline & Day 4 & Day 8 & & \\
\hline Group 1 (1\% CMC) & $203.75 \pm 7.04$ & $189 \pm 7.39$ & 7.2 & $>0.05$ \\
\hline Group 2 (leaf $100 \mathrm{mg} / \mathrm{kg}$ bw) & $208.5 \pm 19.96$ & $68.3 \pm 13.57$ & 67.3 & $<0.05$ \\
\hline Group 3 (leaf 200 mg/kg bw) & $218.8 \pm 15.00$ & $39.0 \pm 15.64$ & 82.2 & $<0.05$ \\
\hline Group 4 (fruit $100 \mathrm{mg} / \mathrm{kg} \mathrm{bw}$ ) & $224.5 \pm 11.254$ & $55.3 \pm 15.13$ & 75.4 & $<0.05$ \\
\hline Group 5 (fruit $200 \mathrm{mg} / \mathrm{kg}$ bw) & $228.8 \pm 6.24$ & $38.0 \pm 14.98$ & 83.4 & $<0.05$ \\
\hline
\end{tabular}

\section{DISCUSSION}

Memory is the ability of an individual to record sensory stimuli, events, information etc, retain them over a short or long period of time and recall the same at later date when needed. Learning is the process of acquiring knowledge about the world and memory could be considered as the retention of the acquired knowledge, which can be recalled as and when needed. ${ }^{11}$

Aegle marmelos (Bael) is an Indian plant, having enormous therapeutic value. The crude extracts have shown various activities including antipyretic, anxiolytic, antidepressant, antiulcer, antiallergic, antidiabetic, antidyslipidaemic, anti-oxidant, anticancer, radio- 
protective, antimicrobial, insecticidal, antifungal, antidiarrhoeal, antimicrofilarial, immunomodulatory, neuropsychopharmacological effects and antispermatogenic properties. Many active phytochemical constituents like coumarins, alkaloids and steroids have been isolated from various parts leaf and fruit of Aegle marmelos. Skimmianine, aeglin, rutin, Y-sitosterol, $\beta$ sitosterol, flavone, lupeol, cineol, citral, sterols, glycoside, halfordiol, marmeline, citronellal, cuminaldehyde phenylethyl cinnamamides, eugenol, marmesinin from leaf aegeline, marmeline, luvangetin, aurapten, psoralen, marmelide, tannin, pectin, xanthotoxol, imperatorin, riboflavin, vitamin-C from fruit. ${ }^{12}$

In elevated plus maze, transfer latency period 2, 3, 4 and 5 there was significantly decrease in latency period 10.5 , 6.8, 10.3 and 7.0 seconds respectively, from 35.3 seconds in control group. This indicates that group 1 treated with $1 \% \mathrm{CMC}$ i.e. the time taken by the animal to enter the closed arm from the open arm was recorded. In the treatment groups had no effect on transfer latency. The findings of the study were comparable to that of Jena Monalisa et al. ${ }^{13}$

In Hebb Williams maze, transfer latency period 2, 3, 4 and 5 there was significantly decrease in latency period $68.3,39.0,55.3,38.3$ seconds respectively, from 189.0 seconds in control group. This indicates that group 1 treated with $1 \% \mathrm{CMC}$ i.e. Time taken by the animal to reach the reward chamber from the start box they had no effect on transfer latency. The findings of the study were in comparable to that of Yashashwini. ${ }^{14}$

The findings of the present study indicate that Aegle marmelos leaf and fruit extract treated animals at a dose of 100 and $200 \mathrm{mg}$ per oral showed significant decrease in transfer latency from day 7 to day $8(\mathrm{p}<0.05)$ but the percentage reduction was more with higher dose of leaf and fruit extract as seen in Table 1.

These findings demonstrate the facilitatory effect of Aegle marmelos on learning and memory. The phytoconstituents like flavonoids, saponins, quercetin, phenols, skimmianine sterols and ascorbic acid have a role in learning and memory. ${ }^{15}$ No toxicological effects were observed at these doses. Hence due to the presence of these phytoconstituents in Aegle marmelos and other herbal plants play a role in learning and memory.

\section{CONCLUSION}

In this study it shows that leaf and fruit extract of Aegle marmelos improves learning and memory. This may be due to presence of phytoconstituents like flavonoids, tannins, sterols and polyphenols. Further studies in this are needed in this field as the drawback of this study is ascertaining the mechanism of action for its learning and memory activity is beyond the scope of the present study.
Funding: No funding sources

Conflict of interest: None declared

Ethical approval: The study was approved by the Institutional Ethics Committee

\section{REFERENCES}

1. Ingole SR, Rajput SK, Sharma SS. Cognition enhancers: Current strategies and future perspectives. CRIPS. 2008;9(3):42-7.

2. Zulfiker AHM, Mahbubur RM, Kamal HM, Hamid $\mathrm{K}$, Mazumder MEH, Sohel RM. In vivo analgesic activity of ethanolic extracts of two medicinal plants - Scoparia dulcis L. and Ficus racemosa Linn. Biol Med. 2010;2(2):42.

3. Patsnaik AK, Kodati D, Pareta SK, Patra KC, Harwansh RK. Analgesic and anti-inflammatory activities of Buchanania lanzan spreg. Roots. Res J Pharm Biol Chem Sci. 2011;2(1):420.

4. Aswatha ram HN. Herbal formulations and their standardization. In: Trivedi PC editors. Medicinal plants traditional knowledge. 1st Ed. India: I.K International Pvt Ltd; 2006: 1-2.

5. Saroj K, Manish M, Tonpay SD. Anxiolytic and antidepressant activities of methanolic extract of Aegle marmelos leaves in mice. Ind $\mathbf{J}$ Physiol Pharmacol. 2010;54(4):318-28.

6. Amberker MV, Tara S, Kumari MK, Bairy KL, Smitha S. Evaluation of anti-inflammatory and analgesic activities of alcoholic extract of Kaempferia galanga in rats. Ind J Physiol Pharmacol. 2011;55(1):13-24.

7. Wahid AM, Suyog DM, Suraj BJ, Ajinkya MP, Mukhtar SK, Madhukar RV. Evaluation of antiinflammatory and analgesic activities of ethanolic extract of roots Adathoda vasica linn. Int J Pharm Res. 2010;2(2):1364-8.

8. Himani, Pratap S, Verma RC, Leve S, Sachan A Dixit RK. An experimental study to evaluate the effects of Aegle marmelos and it's comparison with Piracetam on learning and memory in Wistar rats. Int J Pharm Sci Res. 2013;4(4):1591-7.

9. Parle M, Singh N. Animal models for testing memory. Asia Pacific J Pharmacol. 2004;16:101-20.

10. Parle M, Vasudevan M, Singh N. Swim everyday to keep dementia away. J Sport Sci Med. 2005;4:37-46.

11. Chakravarthi KK, Ramakrishna A. Beneficial effect of aqueous root extract of Glycyrrhiza glabra on learning and memory using different behavioural modes: experimental study. J Nat Sci Bio Med. 2013;4(2):420-5.

12. Rishabha M, Kumar A, Singh A, Kulkarni GT. Pharmacological screening, ayurvedic values and commercial utility of Aegle marmelos. Int $\mathbf{J}$ Drug Dev Res. 2012;4(1):28-37.

13. Monalisa J, Mishra S, Pal A, Mishra SS. Memory Enhancing Activity of Eclipta Alba in Albino Rats: ACorrelation with Anticholinesterase Activity. IJPCR. 2014;6(2):179-85. 
14. Yashashwini YC. Evaluation of learning and memory enhancing activity of coccinia grandis fruits in rats. $\mathbf{J}$ Drug Delivery Therap. 2018;8(5):430-6.

15. Patel PK, Sahu J. Aeglemarmelos: A Review on its Medicinal Properties. Int J Pharm Phytopharmacol Res. 2012;1(5):332-41.
Cite this article as: Kumar $\mathrm{P}$, Krishnakanth $\mathrm{K}$, Alla J. Effect of Aegle marmelos methanolic extracts of leaf and fruit pulp on learning and memory in albino rats. Int J Basic Clin Pharmacol 2020;9:403-7. 